\title{
Assessing international capital mobility in East Asian economies: a panel error- correction approach
}

\begin{abstract}
This study assesses financial integration and the degree of international capital mobility in the East Asian region by analyzing the dynamics of national saving-investment relationships. Following the work of Pelgrin \& Schich (2004), we interpret the close relationship between national saving and investment in the long run reflecting a solvency constraint and focus on the short term saving investment analysis relationship to assess the degree of capital mobility. Applying the panel error -correction technique proposed by Pesaran et al. (1999), our empirical results suggest that there exists a long-run relationship between saving and investment and that the short-run is driven by the extent of the gap between current and longrun equilibrium values. The low estimated values of the short-run coefficient of the changes in the saving rate signal some degree of capital mobility.
\end{abstract}

Keyword: Dynamic heterogeneous panels; Feldstein-Horioka puzzle; International capital mobility 